\title{
Kafka on gender, organization and technology: The role of 'bureaucratic eros' in administering change
}

\section{Marinus Ossewaarde (iD)}

Universiteit Twente Ringgold standard institution - Public Administration

\section{Correspondence}

Marinus Ossewaarde, Universiteit Twente Ringgold standard institution - Public Administration, Drienerlolaan 5, Enschede 7500 AE, The Netherlands.

Email: m.r.r.ossewaarde@utwente.nl
In this article, it is argued that Kafka's novels are satirical portraits of the workings of 'bureaucratic eros' in gendered organizations. In Kafka's tragi-comical fiction, a sexually perverse and uncreative 'bureaucratic eros' - the opposite of the 'poetic eros' - administers highly sexualized gender relationships in hierarchical organizations: law, bureaucratic regulation, administration and execution are expressions of the male officials' sexual desires. Given the lustful manifestations of 'bureaucratic eros', Kafka reveals that organizational and technological change is not some process of rationalization (as Max Weber suggests), but, instead, must be poetically understood as metamorphosis. In Kafka's comical portraits of metamorphoses, the remnants of old myths, old desires, tribe-like organizational forms and primitive uses of technology continue to operate in distorting, disorienting, sexually perverse ways. Thereby, 'bureaucratic eros' brings about an incomprehensible world of lawlessness and anxiety - a deplorable condition that, Kafka suggests, can only be overcome by fleeing administrative dictates, into the aesthetic sphere.

\section{KEYWORDS}

bureaucracy, Kafka, metamorphosis, technology, Weber

\section{1 | INTRODUCTION}

The use of novels to study organizational phenomena is 'a well-established methodological tradition' (Rhodes \& Westwood, 2016, p. 238). In the 1950s, William H. Whyte investigated organizations in contemporary fiction, to illustrate his thesis of the rise of the 'organization man' - a bureaucrat who takes the vows of organizational life, who is mastered and dwarfed by his worship of organization (Whyte, 1960, p. 237). In the 1960s, Dwight Waldo (1968) argued that 'administrative novels' are very important reading material for organization scientists. ${ }^{1}$ The novels of 
Franz Kafka, in particular, enrich the imagination of work and organization, but do not in any way replace studies of work and organization. In fact, the novelist and the scientist can learn from each other (Waldo, 1968, p. 41). In the past two decades in particular, scholars have increasingly turned to novels to make sense of organizational life (Huber \& Munro, 2014; Land \& Śliwa, 2009; Nasir, 2012; Patriotta, 2015). Scholars have turned to novels for new inspiration and insight (Beer, 2016; de Cock \& Land, 2005; Land \& Śliwa, 2009; Vachhani, 2015). Huber and Munro (2014, p. 260) argue that 'the fictional aspect of literature can complement other empirical approaches to the study of organization'. De Cock and Land (2005, p. 529) point out that novels can 'provide the place where ideology is exposed, revealed as something that can be questioned'. Patriotta (2016, p. 568) claims that 'novels provide a useful template for ontological inquiry into organizations'. Rhodes and Westwood (2016, p. 236) stress that novels can be used as 'a means to garner insight into the realities of organizational life', so that we can 'better theorize organizations and organizing'. Vachhani (2015) stresses that studies of the novel make us more sensitive to affective connections, experiences and relations in studies of work and organization.

More than any other novelist, Kafka provides a portrait of what Waldo (1968, p. 2) calls the 'Era of Organization', for instance, an epoch that is characterized by the expansion and impact of planned and formal organizations in daily life. In Kafka's novels, the 'Era of Organization' appears, as Benjamin (2007, p. 112) puts it, as 'the world of offices and registries, of musty, shabby dark rooms', administered by hordes of disoriented messengers, doorkeepers, head porters, commandants, bank employees, clerks, policemen, judges, assistants, commissioners, secretaries, lawyers, mayors, priests, washerwomen, etc. Kafka provides a satirical portrait of, typically masculine, attempts to rationalize the world. In his literary imagination, organizational and technological change is artistically understood as metamorphosis. Mikhail Bakhtin (1981) explains that, for artists,

metamorphosis serves as the basis for a method of portraying the whole of an individual's life in its more important moments of crisis: for showing how an individual becomes other than what he was. (p. 115)

In Kafka's parables, the administrative mechanisms of rationalization produce changes, reforms, restructurings, readjustments and technological revolutions that assume the form of 'entanglements of concrete absurdity' (Buber, 1991, p. 348). In the metamorphosis, there is no progress and no historical process: there is only Babylonian confusion and labyrinthian disorientation. In metamorphoses, the remnants of old myths, old desires, tribe-like organizational forms and primitive uses of technology continue to operate in distorting ways. Understanding administrative change as metamorphosis means that, as Walter Benjamin (2007, p. 131) puts it, 'everything forgotten mingles with what has been forgotten of the prehistoric world, forms countless, uncertain, changing compounds, yielding a constant flow of new, strange products'.

Kafka's vision of metamorphosis is an expression of what Paul Valéry (1989, p. 161) calls 'the artist's antipathy for progress'. And indeed, Kafka is a Dionysian, not an Apollonian writer: change goes hand in hand with trance, orgies, drunkenness and descent to an underworld (Mishara, 2010, pp. 24-25). And the metamorphosis triggers no real surprise: the absurd is taken as a matter of course. Kafka's protagonists always find themselves caught up in a metamorphosis. Defined in terms of their occupational identities, such as bankers, engineers, administrators, land surveyors, doctors, etc., they typically transform themselves into something strange, such as into accused (but never innocent) victims, social outcasts or cockroaches; or they experience an awful fate. This article seeks to show that, in Kafka's satires, the administrative mechanisms that generate metamorphoses are portrayed as devices for performing a 'bureaucratic eros' (Deleuze \& Guattari, 1986, p. 57) that defines highly sexualized gender relationships and reproduces circles of sexual domination (Collinson \& Collinson, 1996). Bureaucratic regulation, administration and execution are all expressions of the typically male officials' sexual desires that define, among other things, the situation of women at work. 'Bureaucratic eros' shapes what Hearn (2014) calls an 'organization sexuality', which is a sexuality constructed through administrative structures and processes that are typically patriarchal, hierarchical and violating. With his focus on 'bureaucratic eros' and metamorphosis, Kafka's aesthetic understanding of change strongly differs from Max Weber's understanding of change as rationalization. Ultimately, Kafka suggests that, given the workings of a perverse and uncreative 'bureaucratic eros', organizational and 
technological change is doomed to bring about not the hoped-for salvation, but, instead, an incomprehensible world marked by lawlessness and anxiety - a deplorable condition that can only be overcome by fleeing administrative dictates. ${ }^{2}$

\section{2 | 'BUREAUCRATIC EROS': UNDERSTANDING ORGANIZATION SEXUALLY}

In Kafka's tales, organizations are highly sexualized and gendered. Ultimately, organizations, and the situation of men and women at work, are shaped by a 'bureaucratic eros' that manifests itself in the perverse sexual desires of typically (but not exclusively) male officials. With his focus on the administrative workings of 'bureaucratic eros', Kafka's portrait of bureaucracy radically differs from Max Weber's well-known ideal types of bureaucracy and rationalization (Ossewaarde, 2013). There are many understandings that Kafka and Weber share (Beck Jørgensen, 2012; Huber \& Munro, 2014; Munro \& Huber, 2012; Rhodes \& Westwood, 2016; Warner, 2007). Kafka shares with Weber a deep cultural and technological pessimism (Warner, 2007, p. 1020). ${ }^{3}$ Both Kafka and Weber are concerned with decadence, not with 'progress'. They both express their pessimism regarding the prospects of rationalization in vivid uses of the imagery of the 'cage' (Warner, 2007, p. 1019). Kafka and Weber share the dark vision that the administrative and technological mechanisms of rationalization tend to generate more domination than liberation. But they radically disagree on the role of eros in work and organization. For Weber, bureaucracy is a 'desexualized sphere' (Fleming, 2007, p. 242) in which eros is eliminated, whereas for Kafka it is the opposite, a 'sexualized sphere'. In Kafka's tales, bureaucracies are presented as 'sexual spaces' (Pullen \& Thanem, 2010): sexuality is performed in relation to, and in forms of, work, organization and technology.

While in Kafka's novels bureaucracy is facilitated by the performance of sexuality (cf. Deleuze \& Guattari, 1986, pp. 42, 51), in Weber's scientific works bureaucracy drives out erotic desire (McCabe, 2015). For Weber, a 'bureaucratic eros' is a contradiction in terms: bureaucracy and eros rule each other out. According to Weber (1958, pp. 343, 347), eros is 'the greatest irrational force of life' and 'the kernel of the truly living'. Sexual desire is creativity's primeval source that is repressed by bureaucracy. Eros, Weber explains, is a creative impulse that can only rule in spheres that escape calculation (Shilling \& Mellor, 2010; Whimster, 1995). Only the erotic sphere, Weber (1958, p. 347) stresses, is 'eternally inaccessible to any rational endeavour'. The erotic sphere is the only nonrationalizable sphere that can transmute physiological (sexual) energies of natural, organic procreativity into energies of potency and creativity. In other words, the erotic sphere, characterized by soul-stirring, frenzy, flirting, sensual responses, heart bleeding and so forth, contains the creative potential to mitigate modern disenchantment (cf. Shilling \& Mellor, 2010, p. 442). Other spheres - Weber distinguishes between the religious, economic, political, aesthetic and intellectual spheres - can be wilfully organized. These are spheres that can be subjected to goal-oriented rational endeavour, to bureaucratic regulations, ordering routines, calculations, conventions, procedures, protocols and legalrational authority.

According to Weber, the administrative mechanisms of rationalization cleanse all spheres - except the impenetrable erotic sphere - from erotic desire. Bureaucracy expunges erotic relations from office lives (Fleming, 2007). Not so for Kafka, for whom bureaucracy does not replace but transform the creative eros into an administrative force. The metamorphosis of eros in the 'Era of Organization' is such that it loses its poetic connection with love, creativity, artistic refinement and beauty. 'Bureaucratic eros' is not expressed in aesthetic and intellectual creations but in obscene letters, perverted reasoning, sadism, delusion, domination, torture and humiliation. 'Bureaucratic eros' is de-eroticized and depersonalized into pornographic desire that facilitates administration and is at the heart of technology design. ${ }^{5}$ Through 'bureaucratic eros', organizations pervade the body pornographically. In Kafka's novels we find that everything, including the law itself, is obscene, driven by a dirty 'bureaucratic eros' and the corresponding 'bureaucratic displacement of intimacy' (Kerfoot \& Knights, 1998, p. 20). In The Trial, we find that the judge's law book contains only pornographic pictures. Bureaucratic proceedings at work are disrupted when a man begins to 
violently kiss a washerwoman in the back of the courtroom. A law student physically removes her, only to kiss her before taking her to the examining magistrate. And the magistrate never thinks in terms of the law or justice: he only has the washerwomen, as the object of his pornographic lust, on his mind. And then her husband arrives and tells the bewildered Josef $\mathrm{K}$. that she consensually turns herself into a sexual object for the Dionysian, orgiastic court officials (Deleuze \& Guattari, 1986, p. 49; Litowitz, 2002, p. 118; Schaffner, 2012, pp. 199-202). The washerwoman, then, is not a plaything in the hands of the powerful rulers of the court: she is an agent who wilfully accepts the gendered status quo that is shaped by 'bureaucratic eros'. The sexual officialdom of the court appears contaminating: during the trial, Josef K.'s own sexual desires for women other than his girlfriend Elsa are violently unleashed.

Also, in Kafka's other stories, characters are largely governed by 'bureaucratic eros'. In Metamorphosis, Gregor Samsa is an 'organization man' who transforms into a cockroach. He loses his human body but not yet his libido. When his bedroom is cleared, he desperately sticks to the pornographic portrait of a lady in furs. And this is something that his sister cannot tolerate (and therefore she abandons him): she is jealous of the picture (Deleuze \& Guattari, 1986, p. 15; La Farge, 2011). In The Castle, an official associated with the fire brigade, Sortini, declares his love to Amalia in the form of a pornographic letter. When the harassing official is refused by the young girl, the townsfolks come to ostracize her. In their self-administration of justice (i.e., justice defined as the expression of 'bureaucratic eros'), they spectacularly scapegoat Amalia and her family, in fear of revenge by the officials (Beck Jørgensen, 2012, p. 203; Corbella, 2007, pp. 78-79; Huber \& Munro, 2014, p. 264). A similar tale can be found in the short story A Country Doctor, when the old doctor leaves behind his mistress, Rosa, a beautiful young girl, in the hands of a lustful, vampire-like groom (who brutally violates her), so that he can visit a patient in some remote village (Engelstein, 2006). Also, in The Castle, K. has dirty consensual sex with Frieda on a filthy, beer-stained pub floor, for many hours, so as to get access to a distant bureaucratic authority, Director Klamm, he wishes to speak (Frieda is Klamm's mistress). Both K. and Frieda mimic the organizational processes of masculine rationality and sexuality of the castle, which is to say that their sex, marked by domination and submission, is reduced to an instrumental goal.

In America, the young Karl Roßmann, who has migrated to the New World to escape the scandal of his seduction by a housemaid, is the lust object of sadistic women - a comical re-imagination of the Lilith, that is, evil female demons, as presented in Jewish folklore (Schaffner, 2012, p. 205). In The Penal Colony, we find a naked prisoner lying on his belly, subjected to awe-inspiring, gruesome torture technology. The naked man is punctuated by rows of needles that engrave the death sentence on his accused body; and he is killed off by a spike driven into his head (Benjamin, 2007, p. 133; Cooke, 2014, p. 635; Litowitz, 2002, p. 122). 'Bureaucratic eros' contains a sadomasochistic lust for executing the death sentence. In other words, 'bureaucratic eros' can also be found in technology design (a killing machine) and in the use of technology as a sexual and enchanting spectacle. The killing machine is not merely designed as a tool for executing the death sentence, but, more significantly, signifies machine-mediated orgy. It is a totem that enables the community of devotees to have an orgiastic experience that is mediated by a machine (cf. Hearn, 2014). In Kafka's comedies, 'bureaucratic eros' imbues administrative praxis as an exercise of authority. Kafka presents organizations as 'sexualized spheres' in which depersonalized sexual relations are enforced in offices and dark rooms, dirty pub floors and bizarre machineries. For Kafka, sexual liaisons do not express resistance to administrative hierarchy - for Kafka, sex has no emancipatory potential in the economic sphere - but, instead, in organizations the libido is sublimated within structures of bureaucratic control and masculine domination (Deleuze \& Guattari, 1986, p. 57). In The Castle, villagers are agents who recognize but do not contest the Dionysian, lusty essence of officialdom. 'Official decisions are as shy as young girls' say the villagers. And K., otherwise so contemptuous of the backwardness of the villagers, enthusiastically agrees with such bureaucratic sexism, exclaiming that 'decisions may have even other characteristics in common with girls' (Benjamin, 2007, p. 115). In The Castle, women are agents who consent to the sexual domination of Faustian officials who use them briefly as their mistresses and then discard them; strangely enough they themselves attribute immense romantic significance to these liaisons. Only Amalia resists pornographic officialdom. She is immediately ostracized: such disobedience to abusive officials disintegrates the whole social fabric of the castle village. 


\section{3 | METAMORPHOSIS: UNDERSTANDING CHANGE AESTHETICALLY}

In Kafka's stories, bureaucracies are the ambiguous objects of his comedies; and as such invested with the provocative qualities of prose. Given that bureaucracies appear as hotbeds of desire, passion and sexual perversity, Kafka's portrait differs from Weber's ideal type of bureaucracy. In Kafka's fiction, bureaucracies are not at all marked by the goal-oriented rationality, disenchantment and strict adherence to procedures and administrative dictates that Weber attributes to bureaucracies. On the contrary, Kafka's novels are characterized by a 'Kafkaesque logic of bureaucracy' (Hodson, Martin, Lopez, \& Roscigno, 2012, p. 257): bureaucratic politics marked by divergent goals, patrimonialism, unwritten rules, arbitrary decision-making, confusion, misunderstanding, caprice, deceit, violence, fear, coercion, personal power, masculine domination and officials' lustiness are foundational in day-to-day administrative operations. Kafka and Weber fundamentally differ in their understanding of change in the modern world: while Weber understands change scientifically as rationalization, Kafka understands change aesthetically as metamorphosis. Rationalization makes change comprehensible; metamorphosis - to a large extent driven by 'bureaucratic eros' - makes change incomprehensible (Mishara, 2010). Waldo (1968, p. 5) notes that Kafka's aesthetic notion of metamorphosis that he uses to make a comedy of the world of work and organization manifests a certain 'hostility of the man of letters towards the world of organization' that is absent in Weber's scientific (and critical) notion of rationalization. Such hostility, Theodor Adorno (1981, p. 106) explains, inheres in 'the tradition of the novel, which has as its object the conflict of human beings with rigidified conditions'.

While Kafka displays an aesthetic understanding of change defined as metamorphosis (thereby championing the poetic values of the aesthetic sphere), Weber's science is marked by an intellectual understanding of change defined as rationalization. In Weber's terminology, in the 'Era of Organization', value rationality of intellectuals and artists tends to give way to the goal-oriented rationality of lawyers, engineers, managers, planners, land surveyors, etc. Weber is the scientist who manifests his sociological imagination, constructs his abstract concepts (ideal types) and interprets rationalization as a historical process of disenchantment. Kafka, by contrast, creates aesthetic (typically unsympathetic and sexually perverse) figures of the 'organization man' who works in (and is controlled by) a bureaucratic organization that is shaped by 'bureaucratic eros' (cf. Ståhl, 2016, p. 229). Kafka makes a comedy of the (potentially) aesthetic figure as a character that is dominated by frightening administrative mechanisms of change - and these mechanisms are presented as disorientating and distorting forces of metamorphosis. While Kafka provides a critical aesthetic assessment of organization and administration, Weber passes a critical intellectual (sociological) judgement. ${ }^{6}$

Weber and Kafka seem to agree that administrative mechanisms are erected to enforce bureaucratic procedures, which are merely official formulations of what and who is to be obeyed (Barnard, 1954, pp. 3-5). In Kafka's stories, such formulations are typically of a sexual kind, triggered by an irresistible 'bureaucratic eros'. The problem of such bureaucratic dictates, for both Weber and Kafka, is that they tend to replace the law, which is to say that administrative mechanisms tend to enforce a legal yet lawless or illegitimate condition. ${ }^{7}$ Weber and Kafka seem to agree that what is meant by the law is the complex of laws that emerge from different value spheres. The aesthetic sphere (of the novel) and the intellectual sphere (of organization studies, gender studies, etc.) that Weber so carefully distinguishes are regulated according to their own given laws that no administrative mechanism can legitimately overrule. The laws of the aesthetic sphere, or, more specifically, the laws of the literary field (cf. Bourdieu, 1993, pp. 162-163), are legislated by what the novelist Ismail Kadare has called 'the bosses of world literature: Dante, Shakespeare, Goethe, Kafka' (Ossewaarde, 2015). Kafka is an artist who writes under the laws of the literary field (Deleuze \& Guattari, 1986, p. 91). His writings are 'by their nature parables' (Benjamin, 2007, p. 144). As a 'boss of world literature', Kafka legislates the laws of the literary field, in the sense that his stories signify a radical reassessment and redefinition of thought and feeling. They are an attempt to revolutionize imagination, emotion and desire (cf. Heller, 1988, p. 113). ${ }^{8}$ As a revolutionary legislator of the literary field, Spurr (2011, p. 186) explains, Kafka wants to prove himself as a writer on his own terms, even if his writing is of no importance to the world and its administrators. Weber, by contrast, writes under the laws of the intellectual sphere, or more specifically, the laws of the scientific field. The laws 
of the scientific field are legislated by the bosses of science, like Newton (mechanical science), Vico (new science), Nietzsche (joyous science) and Weber (interpretive science) himself. As a great innovator of (social) science, Weber's texts are an attempt to revolutionize scientific thinking and empathic understanding in an industrial world that is marked by mechanization and the industrial technological and bureaucratic crushing of Kultur (Ossewaarde, 2013). Weber's interpretive sociology is a value-rational science created both for making sense and for resisting the administrative mechanisms of rationalization, in defence of the laws of the intellectual sphere (i.e., in defence of academic culture).

In 'Science as a Vocation', Weber (1958, pp. 129-156) sadly witnesses the rationalization of the intellectual sphere as a historical process - more specifically, he points at the bureaucratization of 'German university life' (Weber, 1958, p. 131). Weber explains that originally the intellectual sphere, and academic existence, is informed by the value-rational quest for reflection, erudition, demonstration, clarification, empathy, inquiry, wisdom. The type of $\left(19^{\text {th }}\right.$-century) German university that Weber represents was originally established for the realization of the romanticist Bildungsideal. 'The "cultivated" personality formed the educational ideal', Weber (1958, p. 243) explains. For Weber, indeed, the purpose of his interpretive science is to contribute to the fulfilment of humanity's existential potential - a potential that comes to fulfilment in the academically educated Kulturmensch - the very opposite of a soulless bureaucrat. The rationalization of the intellectual sphere, Weber (1958, p. 131) argues, means that science develops 'in the direction of the American system', to the point that science becomes administered, that is, subjected to administrative dictates and shaped by administrative mechanisms. Science becomes a problem of calculation that is chained to (rather masculine notions of) planning, control and technological innovation. Also, transformed into bureaucracies, universities come to provide certificates and 'trained expertness that is increasingly indispensable for modern bureaucracy' (Weber, 1958, p. 240). In a similar scientific analysis, Whyte (1960) describes how bureaucratized universities come to mould scientists - knowledge workers - in accord with the image of the organization. 'Like his brother in management', Whyte (1960, p. 201) explains, 'the scientist is becoming an organization man', whose intellectual activities come to be organized in research designs, planning, targets, formats, projects, rankings, publication lists, budgets and teams - marked by a pervasive language of competitiveness and instrumental rationality that Kerfoot and Knights (1998) identify as masculine domination. Such is the breakdown of the laws of the scientific field in the 'Era of Organization'. Weber borrows the metaphor of the iron cage from John Bunyan's The Pilgrim's Progress, to show how, with the replacement of the laws by administrative dictates, the European Kulturmensch or 'cultivated personality' is replaced by the anonymous, spiritless, replaceable and disciplined 'bureaucrat' who administers society.

Also, in Kafka's comedies, we find that the autonomy of spheres is usurped. Yet, for Kafka, in contrast with Weber, the invasion of the spheres by bureaucratic rulings is not a historical process of rationalization and disenchantment of the world but, instead, a structural condition that is marked by metamorphosis and corresponding labyrinthian disorientation. In whatever epoch Kafka describes, be it ancient China or modern America, people at work always appear subject to bewildering organizational forces (regulations, administrations, trials, executions, judgements, plans, projects, etc.) (Munro \& Huber, 2012, p. 532). Whyte stresses that for an 'organization man' to become master of his own destiny, he must resist such forces. 'Fight he must, for the demands for his surrender are constant and powerful', Whyte (1960, p. 372) explains. In Kafka's fantasy world of offices and registries, given the mediocrity and sort of passions of the protagonists, such heroic resistance is rarely an option. In metamorphoses, given the lusty manifestations of 'bureaucratic eros', there is only a limited possibility for agency. Kafka's protagonists do not master events: they are caught up in events. Their fate is decided by bewildering organizational forces and sexual desires they cannot control. In The Castle, K., in his struggle for rights, tries to resist. K. is certainly an agent who has a strong will of his own. But his attempt to assert himself in the castle assumes the form of a poisoned, unheroic, vengeful attitude. And when he is contaminated by 'bureaucratic eros' and enjoys the sexual dimensions of officialdom, in his relationships with women, he is eager to surrender and go along with the administrative (sexual) proceedings (Keenoy \& Seijo, 2010). Rather than heroically fighting and resisting, Kafka's (rather unheroic) protagonists typically have the option to flee the administrative apparatus, that is, to die or to escape into the aesthetic sphere, where they can be creative (Munro \& Huber, 2012, p. 537). In the organization, employees like Gregor Samsa 
are perverted into spiritless, even barbarous figures; in the aesthetic sphere they may become cultivated. In the aesthetic sphere they are not administered through the performance of 'bureaucratic eros': they can be creative. Huber and Munro (2014, p. 265) emphasize that Kafka emphasizes 'the impossibility of the realization of transcendental values within organizations'. Indeed, for Kafka, emancipation is only possible outside the organization and its 'bureaucratic eros', through escape into the aesthetic sphere - the sphere in which sexual desires may become refined, eroticized, through the workings of the 'poetic eros.' ${ }^{10}$

Waldo (1968) stresses that the artistic purpose of the administrative novel is the same as the scientific purpose of organization studies: to make the world of work and organization become alive and as understandable and as dramatic as possible (cf. Beer, 2016, p. 409). In defence of the laws of the scientific field, Adorno (1981, p. 245) emphasizes that it would be wrong to turn Kafka's art into 'an information bureau of the human condition'. Adorno stresses that Kafka's fiction cannot be used as a documentary resource of the intellectual sphere. Given that Kafka writes parables, the question is to what extent he, being an artist, is a trustworthy voice in garnering insight into the bewildering realities of organizational life and its gender relationships. ${ }^{11}$ In many ways, Kafka fictionalizes the theoretical imagination that can be found in scholarly writings like Weber's, to the point that he comically provokes scientific theorizations and challenges the scientific imagination, or even the scientist as such (cf. Beer, 2016, p. 411; Harrington, 2007). In Kafka's novels, the scientist is portrayed as an aesthetic figure (typically presented as a dog, like the researcher in his short story Investigations of a Dog), whose hunger for knowledge is a mask for the less lofty desires (such as the real hunger of a street dog or a country doctor's lust for a girl (a theme that can also be found in Goethe's Faust, with Dr Faust seducing the young Gretchen). More than Weber's scientific writings on bureaucracy and rationalization, Kafka's comedies are artistic expressions - new literary expressions - of unheard experiences of working, relating, gendering and living in organizations. The Trial, The Castle, America, The Penal Colony, Metamorphosis, The Judgement, A Country Doctor, they are all offsprings of a new literary imagination, artistic expressions of ideas that had as yet not been articulated, not even in the intellectual sphere. And they are written to evoke horror or laughter, or simply to generate refined aesthetic delight (cf. Heller, 1988, pp. 108-109, 2009, pp. 173, 179; Ståhl, 2016, p. 229).

Kafka interpreters like Klaus Mann and Berthold Brecht have argued that, with his comical description of bewildering organizational forces, Kafka anticipates the rise of Naziism and its brutal attack on the laws of the aesthetic and intellectual spheres - characterized by the burning of books (including Kafka's novels) and other forms of art (Adorno, 1981, p. 259; Danoff, 2000; Robertson, 1985, p. 96). Although in Kafka's tales the grim reality which eventually came to pass can certainly be discerned (Roshwald, 2005, p. 374), Kafka (in contrast with Weber) does not describe any historical process (like the rise of Naziism). ${ }^{12}$ In line with the laws of the literary field, Kafka poetically narrates metamorphoses. As the sudden arrests, arbitrary decrees, orgiastic courts, penal colonies, orgiastic executions, etc. that he describes are typical phenomena of tyranny that can be found in all epochs, no political far-sightedness, scientific prediction or religious 'prophetic vision' must be attributed to his novels, as Benjamin (2007, p. 143) emphasizes. ${ }^{13}$ It is not Kafka but George Orwell who describes the totalitarian bureaucracy. In contrast with the 'Kafkaesque logic of bureaucracy', the Orwellian nightmare is one in which the aesthetic sphere offers no refuge (or potentiality of transcendence or emancipation) because it is, like all other spheres (including the erotic sphere), under bureaucratic control. In the Orwellian nightmare, the world has become an organization characterized by the omnipresent surveillance of Big Brother, Newspeak, the Thought Police and prohibited sex. New technologies enable regime agents to detect and seize the body, the mind and the heart of everyone; and they are technically capable of re-programming everyone. In 1984, Winston Smith is reengineered. Through a sophisticated torture programme he is forced to betray his love and dwarfed into a weeping, submissive, child (Waldo, 1968, pp. 25, 49). By contrast, Josef $K$. is not re-programmed, but radically alienated from other people in his family and at work. Josef K. betrays his girlfriend Elsa because he is moulded by his work and the organization he works for. Being a masculine banker he prefers the formal and hierarchical relations of the bank and the court to Elsa's intimacy and care. In Kafka's tales, the perverse crushing of love and the un-erotic betrayal of lovers only requires taking the vows of organizational life. Love, for Kafka, is the ultimate law of life - the creative force. 


\section{4 | 'BUREAUCRATIC EROS' AND METAMORPHOSIS: THE SPREADING OF ANXIETY}

Waldo (1968, p. 32) singles out Kafka's The Trial and The Castle, along with Joseph Conrad's The Secret Agent, Herman Hesse's Steppenwolf and Albert Camus' The Plague, as the great and rare examples of the administrative novel that have scientific value. What makes Kafka's administrative novels so relevant beyond their aesthetic value is that technology (Kafka frequently refers to machines, telephones, typewriters, cars, mass scale buildings, etc.) and administrative hierarchy - and, correspondingly, the breaking down of machines and administrative error - comically intermingle. ${ }^{14}$ Slavish devotees of the authorities are similar to the tribalistic devotees of the machine. Not only the mysterious castle, but also the punishment machine of The Penal Colony is worshipped as a totem. Both abusive authorities and torture technologies cannot be resisted by devotees. Typically unaffected by art, they lack the existential capacities needed for doing so. Both authorities and technologies condition devotees to their body (alienated from the mind), to their depersonalized sexual life and, ultimately, to death (Deleuze \& Guattari, 1986, p. 56). Both demand from devotees a humiliating, dwarfing submissiveness, to the point that conditioned devotees willingly accept their incomprehensible death sentence (Benjamin, 2007, p. 121; Deleuze \& Guattari, 1986, p. 9). ${ }^{15}$ In Kafka's comedies, bureaucratic regulations offer no legal protection. They are lawless in themselves. Being an official manifestation of 'bureaucratic eros', bureaucratic rules provide the very opposite, namely, sadomasochistic commandments that assume the form of incomprehensible death threats. And technologies appear as the bizarre sex toys employed by officials for the performance of 'bureaucratic eros'.

In Kafka's novels, the omnipresence of the economic sphere of organization, work and technology is described as what W. H. Auden has called the 'age of anxiety' (La Farge, 2011, p. 282; Litowitz, 2002, p. 104; McCabe, 2015, p. 62). In Kafka's satirical portrait, the omnipresence of the castle, as the metaphor of organization, is described as a state of anxiety that is characterized by Babylonian confusion, helplessness and labyrinthian disorientation. More concretely, in Kafka's novels, grandiose plans, technological inventions, intermingled with administrative blunders, miscommunications, false alarms, accidents, injuries and the breakdown of, and mutilations by, machines, are the forces of metamorphosis that generate an existential condition of anxiety. In contrast with the fear of fathers, bosses or strangers that Kafka describes in his tales, anxiety has no concrete object (such as domination) except for the abstract threat to meaningful existence as a Kulturmensch - and this threat comes from organizing. ${ }^{16}$ Paul Tillich (1977, p. 55) explains that 'the anxiety of emptiness is aroused by the threat of non-being to the special contents of the spiritual life', which occurs when 'the creative eros is transformed into indifference or aversion'. Such is indeed Kafka's understanding of 'bureaucratic eros' - a sexual desire that expresses indifference to persons. 'Bureaucratic eros' makes men and women turn away from all concrete contents of love and personhood, only to end up in an abyss of meaningless (loveless and uncreative) existence in which inner-emptiness is filled with unrefined or uncultured desire. ${ }^{17}$ Kafka's understanding of anxiety seems to come from Kierkegaard, who, in his The Concept of Anxiety, found that anxiety is the root and result of the distorted, loveless relationship to oneself and to others and to the world (which in Kafka's fiction, appears a bizarre world of organization and work, filled with abusive authorities, perverse sexual relationships and machines). ${ }^{18}$

Kafka's disoriented protagonists radically experience such distorted relationships, because they are themselves loveless and inwardly empty; and, accordingly, they do not desire something good for the other, but, instead, treat the other as a lust object. In A Country Doctor, the disoriented doctor, acting on a false alarm, lies in bed with his patient. In The Trial, Josef K.'s lawyer wants to dominate his client. In The Penal Colony, prisoners only serve as food for the torture machine, and, therewith, for the sexual satisfaction of the Old Commandant. In The Judgement, the father, the old patriarch, sentences his successful son to death. In Metamorphosis, the helpless Gregor Samsa is abandoned by his sister because she is jealous of a pornographic picture he adores. Given the metamorphosis Kafka's protagonists find themselves in, the intellect itself is disoriented; the disoriented intellect is expressed in the perverse reasoning, folly and oblivion that are found in Kafka's stories. More than Weber's iron cage of rationality, Kafka reveals a grotesque reality of administrative praxis without concern for the inner 
life (minds, hearts and souls) of people, to the point that men and women become things and are treated accordingly by each other and by themselves: without humanity or without subjectivity. Yet, anxiety is an existential condition of distorted relationships to the self and to others and to the world. Anxiety generates particular fantasies - fantasies of escape, including escape from humanity or descent into the underworld, which set a metamorphosis of being in motion.

Mikhail Bakhtin (1981) explains that:

metamorphosis serves as the basis for a method of portraying the whole of an individual's life in its more important moments of crisis: for showing how an individual becomes other than what he was. (p. 115)

The most explicit account of such a transformation of being can be found in Kafka's Metamorphosis. This is the tale of the dutiful and dull administrator Gregor Samsa, who finds it impossible to maintain boundaries between waking and sleeping experiences (cf. Gabriel, 2012, p. 1149). Irksome anxiety appears to affect this 'organization man' through and through, day and night, at work and at home. He wakes up one morning from a nightmare and finds himself changed into a monstrous cockroach. Being afraid of his dominant boss, his only concern is to get to work (Rhodes \& Westwood, 2016; Robertson, 1985, p. 80; Warner, 2007). His consciousness of work and organization is gendered (cf. Collinson \& Collinson, 1996; Hearn, 2014; Kerfoot \& Knights, 1998): once he realizes that he no longer has the body to work (and yet he has not lost his male sexuality), he is afraid that he is not 'man' enough to continue supporting his family; and that he will be ostracized by his family if he fails (La Farge, 2011). If he is to flee from the pressures of work, he cannot remain an administrator. He cannot even remain a human being. Only as a cockroach, no longer bound by exhaustive obligations to his superiors and no longer ruled by the timetable, is Gregor Samsa able to discover his existential, creative possibilities; and thereby accomplish a culturally meaningful existence. Once he comes to discover the laws of the aesthetic sphere as a cockroach, Gregor Samsa is able to shake off his paralysing anxiety and discover his inner-sense. No longer an administrator dictated by bureaucratic procedures and timetables, he comes to appreciate art (music) and perceive beauty, and develops some refined feelings of love (Robertson, 1985, p. 82).

A similar metamorphosis can be found in America. Karl Roßmann manages to escape from the administered economic sphere, marked by soulless efficiency, which dominates the capitalist New World. Like Gregor Samsa, the young migrant manages to flee into the aesthetic sphere (the world of the theatre) and discovers its laws. He does not become a cockroach in the literal sense, but he moves from riches to rags, thereby putting the capitalist American Dream and careerism upside down (Adorno, 1981, p. 265; Robertson, 1985, p. 63). ${ }^{19}$ In the short story The Judgement, Georg Bendemann actually has become a successful merchant, and has become engaged to a girl from a well-to-do family. But Young Georg is judged by his jealous old father, the founder of the firm, and he is condemned to death by drowning. And Georg obeys his father's will. He submits without a struggle, crying softly that he has always loved his parents. In The Great Wall of China, the engineering of the fortification - a technical marvel - is so overwhelming that people are stuck in the army of labour (Benjamin, 2007, pp. 123-124). The fortification is a grandiose project (resembling the Tower of Babel) that is patterned upon the absurd premise, or distorted reasoning, that anxiety can be overcome through the technological bordering of worlds. Architectural schemes are organized for preventing feared peoples, or strangers, from entering (Heller, 2009, p. 177). To realize the project, a metamorphosis is set in motion: armies of labour are mobilized, men and women are uprooted from their village life, their traditions destroyed, their relationships distorted, plunged into construction work. In The Great Wall of China, the peoples of Southern China have no existential opportunities: being sentenced to exhaustive labours, they cannot overcome their anxiety. Forever building the border, they are stuck in the economic sphere; and, accordingly, without access to the aesthetic sphere, remain blind to their inner situation. The gates to worthwhile existence are closed to them. They are dehumanized: they cannot express their creativity.

In other tales, Kafka narrates the metamorphosis in distinct ways. In The Penal Colony, for instance, we find a community of devotees (resembling, in some ways, bacchants) that is governed by the sadomasochistic Old Commandant. The community is structured around a technological totem, a bizarre machine designed for useless torturing and 
the execution of the death sentence (Geddes, 2015). ${ }^{20}$ The Old Commandant is a primitive, traditional authority, an old patriarch, who has himself engineered the totem (Benjamin, 2007, p. 133). In the penal colony, the machine is a device that mechanically performs 'bureaucratic eros'. The Old Commandant is sexually attracted to the machine. For the spectators, the technological execution of the death sentence is tailored as a spectacular sadomasochistic ceremony (Geddes, 2015). Through Dionysian, obscene gestures, they intensify their sensual pleasures and experience the ceremonial performance of justice, including the extreme pains of the prisoner, sexually (Cooke, 2014, pp. 637-638). But then bacchant things do not go as planned. As with the golem in the legend of Rabbi Judah Löw in Prague (cf. Dekel \& Gurley, 2015), the Old Commandant's machine becomes disobedient when it starts becoming hungry for new prisoners. As there are not enough prisoners in stock, it pierces the body of its creator to death. When the New Commandant comes to replace the old one, he does not give attention or credit to the amateurish machine that the colony community devotees had worshipped. Instead, he comes with a grandiose building plan to extend the penal colony's harbour, thereby destroying the social fabric of the community. Frightening and killing as the Old Commandant's fetish is, it does, in mysterious ways, sustain a community of orgiastic devotees. But the visionary New Commandant comes with a utopian vision (Robertson, 1985, p. 154) - an obscure plan that resembles the building of the Great Wall of China or the Tower of Babel; and thereby comes to spread anxiety.

George Steiner (1980, p. 309) observes that 'the chronicle of the modern soul's descent into hell is no Divina Commedia, but the prose fiction of Dostoevsky and Kafka'. And indeed, Kafka's protagonists are, in contrast with the cursed Oedipus, no longer at home in a metaphysical universe or symbolic realm. Instead, they are entrapped in a most bizarre world of dominating organizations and technological totems (Deleuze \& Guattari, 1986, p. 22). Yet, while organizations may enforce the predictable patterns in which men and women may find themselves caged, the unexpected events in which Kafka's protagonists find themselves trapped are governed by fantasies. Josef K., K., Gregor Samsa, Karl Roßmann, they are always part of a noisy apparatus that sucks the life out of them. They project their anxiety from the un-erotic emptiness of their own interior existence to the bizarreness of the exterior world of organization, administrative work and technology. The disgusting cockroach is a perverse inversion of Gregor Samsa's identity of a bossed and insignificant administrator (La Farge, 2011). The old country doctor's young mistress, the beautiful Rosa, exists only in his perverse imagination (Engelstein, 2006, p. 350). Georg Bendemann's dominant father exists in his guilty conscience (which drives him to suicide). The hierarchical structure of the orgiastic court mirrors the hierarchy Josef $\mathrm{K}$. feels so much at ease with in the bank. The questionable trial is only a real trial because Josef $\mathrm{K}$. is so eager to go along with its sadomasochistic proceedings. Even when he is appalled at the prospect of people being whipped at the court, he anxiously remains preoccupied with securing his career (McCabe, 2015, p. 74). And in The Castle, the castle is always blurry, covered in snow, situated nowhere in particular and always inaccessible: its existence as a supreme authority is very much in the deceptive eye of the frustrated and vengeful beholder K. (Corbella, 2007). Just as Director Klamm, as a castle authority, may exist only in Frieda's sexual fantasies.

In an artistic work like Edvard Munch's The Scream (1893), anxiety is expressed in the scream of horror (Heller, 1973, p. 56). Nature is painted as a projection of a man's mood and loss of orientation. In Kafka's tales, there is no nature. Organization, work and machinery replace nature and become the sole objective, grotesque reality in which anxiety does not trigger a scream. ${ }^{21}$ When suddenly arrested for unknown reasons, Josef K. does not scream. His only concern is to find out whether some administrative error has been made. Being a boss at the bank himself, finding himself at home in the hierarchies of banks and courts, he does not attack the court authorities but aligns himself with them. Always trapped within structures of masculine domination, Josef K., in a sadomasochistic manner, submits. He willingly places himself under the distorted judgment of an orgiastic court of men, organized in shabby dark rooms, that sentences him to death. After the court commands him to kill himself, which he refuses, it kills him in a gangster-like, lawless, fashion. The court has two men thrusting a double-edged butcher's knife into Josef K.'s heart and let him 'die like a dog'. At the point of dying, without much will to live, the disoriented Josef K. only feels guilt about not having been able to obey the court's command to kill himself (Arendt, 1994, p. 71; Beck 
Jørgensen, 2012; Buber, 1951, p. 165; Deleuze \& Guattari, 1986, p. 46; Heller, 2009; McCabe, 2014; Munro \& Huber, 2012). Unlike Gregor the cockroach, Josef K. never manages to discover his existential potentialities. ${ }^{22} \mathrm{He}$ lives as an 'organization man': mentally and physically Josef K. takes the vows of the authoritarian life of banks and courts, and self-perpetuates its questionable proceedings (cf. Whyte, 1960, p. 8). Peter Pesic (1994, p. 184) rightly identifies men like Josef $\mathrm{K}$. as 'devilish human beings', who, being submissive administrators in their soul, are defined by their 'willful blindness to their inner situation'. Josef K., indeed, does not scream of horror because, like the peoples of Southern China eternally building the great wall to overcome their fear of the stranger, he is blind to his inner situation. In The Castle, we find yet another expression of anxiety. K. does not scream when it appears that the authorities have actually made an administrative blunder in appointing him as a land surveyor. K.'s anxiety is expressed in resentment. In his eternal struggle to receive confirmation of his appointment from the authorities, the anxious $\mathrm{K}$. is driven by impulses of revenge. In his vengeful quest for justice, he menaces and punishes people and ridicules their traditions whenever he can. Thereby K., the stranger from nowhere, unremittingly reproduces injustice and masculine domination in the castle (Adorno, 1981, pp. 269-270; Beck Jørgensen, 2012, p. 198; Deleuze \& Guattari, 1986, p. 46; Warner, 2007, p. 1024).

\section{5 | DISCUSSION AND CONCLUSION}

Kafka's novels expose an ideology of organizing and administering gender relationships, work and organization. Key in this exposition is Kafka's artistic understanding of bureaucracy change. Kafka envisions management of change, including planning, (re-)designing, (re-)organizing, (re-)structuring, (re-)constructing, (re-)programming, (re-) conditioning, etc., as metamorphosis. The key characteristic of metamorphosis is that the remnants of old myths and primitive forms of work and organization continue to operate in distortive ways, mixing up irreconcilable elements from different epochs and species. Meanings are thereby dislocated. And this literary imagination of change stands in radical contrast to the scientific understanding of change that prevails in organization science. Waldo (1984, p. 19) stresses that 'the doctrine of progress' tends to inform organizing: rationalization, including reform, reorganization or development, always signals a historical process. This is how Weber, a cultural critic of bureaucracy and the doctrine of progress, tends to understand the rationalization process, namely, as a progressive process of cultural regress in which the erotic sphere is increasingly repressed. Kafka's comedies inform us that the administrative mechanisms of rationalization, such as Taylorism, does not deliver a goal-oriented world that is devoid of eros. For Kafka, the 'Era of Organization', as Cooke (2014, p. 634) correctly stresses, is 'a world in which rationality is noninstrumental'. In Kafka's portrait, the impact of planned and formal organizations, such as the court, the castle or even the penal colony, is marked by a bizarre mix of goal-oriented rationality and the remnants of old curses, old prejudices, sexual desires, etc. that distort gender, work and family relationships, and disorient the mind. Kafka's metamorphosis-based portrait of organizational life, which ultimately resolves around the sexually perverse manifestations of 'bureaucratic eros', cannot complement Weber's process-based account of rationalization. Instead, Kafka is the radical alternative to Weber - the 'compelling counter-image to the formal-rational model' (Hodson, Roscigno, Martin, \& Lopez, 2013, p. 1252) indeed. That is, both Kafka and Weber are cultural critics of bureaucracy, but their criticisms are of different kinds.

Kafka imagines the exercise of administrative authority, within professional relations, in terms of the workings of 'bureaucratic eros'. 'Bureaucratic eros' facilitates administrative hierarchy, including gender relationships within organizations, and lies at the heart of organizing, managing and designing. In The Trial and The Castle such (endless) hierarchy can be understood as phallocentric rule, with women and girls being offered to the Moloch of organization, as a form of cultic worship. Such novels seem to be marked by gender bias, as women are portrayed as the tools of male sexual domination. Yet, in America, the young and not so masculine Karl Roßmann is reduced to his sexual utility by sadistic women, in a manifestation of feminine domination. Kafka's fiction illuminates how administrative systems can be understood as sexual constructs that depersonalize intimacy. Gender inequality, of whatever kind, typically 
plays a role in Kafka's stories, if only because, given metamorphosis and anxiety, sexual relationships are distorted. As 'bureaucratic eros' is a brutal degeneration of the 'poetic eros' that belongs to the aesthetic sphere (Vachhani, 2015), Kafka reveals an obscene, sadomasochistic image of organization and management. 'Bureaucratic eros' is not a disruptive or unsettling quality of organizations: it makes organizations run smoothly through sexual domination. $A$ focus on 'bureaucratic eros' makes us sensitive to the sexual liaisons, sexual harassment and sexual abuse that shape so many people's lives within administrative systems. Various organization scholars have documented such sexual domination in organizations (Bell \& Sinclair, 2014, pp. 271-272; Brewis, Tyler, \& Mills, 2014; Collinson \& Collinson, 1996; Hearn, 2014; Kerfoot \& Knights, 1998). And in recent years, this phenomenon of organization has been frequently illustrated by the numerous recent sex scandals in the (typically male-dominated) culture industries, police force, tech firms, charity sector, sports clubs, churches and state institutions, and ISIS' brutal 'bureaucracy of rape' (Younis, 2015). But a 'bureaucratic eros' not only helps to illuminate how administrative systems are invested with misplaced sexual energies (misplaced because such sexual energies help to administer rather than to create). Organizations also produce technological objects for sexual satisfaction. Cluley (2014) gives the example of how in the scientific field peer review processes provide masculine masochistic pleasures among academic fetishists in pursuit of success. In The Penal Colony, it is the Old Commandant's golem, a torture fetish, which provides the sexual satisfaction for an entire community of bacchant devotees.

Kafka's satires of intellectual disorientation, perverse reasoning, orgies, drunkenness and abyss - the unsurprising absurdity that appear normal in the organizational life of the court and the castle - provide portraits of lawless behaviour in administrative settings. Such lawlessness, particularly sexual lawlessness, however, does not imply that, for Kafka, there is no law. On the contrary, there is law for Kafka, but this law is destroyed in organizational life, mainly through the contaminating 'bureaucratic eros' that is such a dominating, invasive force. Weber's theory of spheres enables us to see that the laws originally inhere in the different spheres - for instance, in the form of the laws of the scientific field. Rationalization, however, means that all spheres (intellectual, aesthetic, religious, etc.) are invaded and the laws crushed by administrative mechanisms. Intellectual people, artistic people, erotic people, etc. are, accordingly, replaced by the 'organization man' who is ruled by bureaucratic procedures. And the 'organization man' is, for Weber, a strictly disciplined official who exercises authority in line with the legal rules. Like Weber, Kafka also portrays the invasion of the spheres, but, unlike Weber, he considers the bureaucratic dictate as an unpredictable expression of 'bureaucratic eros' that dominates the 'organization man', whose brutal sexuality is left uncultivated because he has no access to the aesthetic sphere. Sexual desires can only become refined in the aesthetic sphere, as the cultivated expressions of 'poetic eros'. Weber the scientist and Kafka the artist write, of course, in different spheres and under different laws. Kafka's satires of gender relations, lusty authorities, sexualized organization and sexual totems can be understood as a defence of the laws of the literary field. And Kafka's defence of these laws is based on his strongest conviction - the conviction of an artist - that only the aesthetic sphere can provide access to a meaningful existence. This implies that, for Kafka, to live a meaningful life one must, like Kafka himself, transcend work and organization and flee into the aesthetic sphere, where sexuality is cultivated. ${ }^{23}$ Only in the aesthetic sphere can sex - that is sex transcended into refined love - have emancipatory, creative potential.

Kafka's novels enable us to unmask the administrative forces of change as the products, and the producers, of a bureaucratic and technological condition of anxiety. Kafka follows Kierkegaard in his description of this modern condition of anxiety. For Kafka, work and organization are administrative edifices and processes of repression that enforce the condition of anxiety (cf. Munro \& Huber, 2012, p. 537; Warner, 2007, p. 1028). In Gabriel's dramatic case description of a so-called creative knowledge-intensive industry of skilled professionals that underwent a dramatic overhaul we discover a Kafkaesque anxiety production at work (Gabriel, 2012). When a new boss arrives with grandiose plans of turning the organization into a more fanciful object of desire, with a new fancy building (or castle) and fetishism of sexy images, the organization, Gabriel (2012, p. 1145) witnesses, degenerates into 'a state of rottenness', a Dionysian abyss. Gabriel's case study reminds us of the parables of the New Commandant of The Penal Colony and The Great Wall of China, in which metamorphoses generate moral and spiritual decay, corruption of values, 
degraded sexuality, perverse gender relationships, and uprooting of established relations of trust, love and community. For Kafka, this is the metamorphosis that tears us to pieces like a torture machine, unless, being cultivated or humanized agents, we manage to flee.

\section{DECLARATION OF CONFLICTING INTEREST}

The author declared no potential conflicts of interest with respect to the authorship and/or publication of this article.

\section{ENDNOTES}

1 The 'administrative novel' can be contrasted with other types of novels, such as the 'philosophical novel' that can be found in the works of Leo Tolstoy, Robert Musil (in particular The Man Without Qualities), Marcel Proust and Jean-Paul Sartre; 'psychological novel' of novelists like Stendhal (in particular The Red and The Black), Fyodor Dostoevsky, Joseph Conrad (in particular Lord Jim) and Yukio Mishima; or the 'political novel' of writers like Joseph Roth (in particular Radetzky March), Mikhail Bulgakov, George Orwell and Ismail Kadare.

2 McCabe (2014, p. 275) rightly stresses that 'Kafka's work cries out for alternative ways in which to organize and govern ourselves.' In a letter to Max Brod, Martin Buber (1991) beautifully articulates this direction of hope in Kafka's dark novels:

as we concern ourselves with it [Kafkaesque reality] and suffer the entanglements of concrete absurdity, do we not again and again, whether we admit it or not, become aware, in cruel sanctification, of the meaning that proves to be totally uncongenial to us and yet is something that faces us and penetrates all that effluvium and at the last, right moment reaches and occupies the innermost chambers of our heart? (p. 348)

In a similar vein, Max Brod, in a letter to Martin Buber (1991, p. 497) confesses that he sees it as his great task to defend the 'meaning of Kafka's life and work against all misinterpretations that are bent on seeing in him only an expression of the labyrinth of the world without any way out'.

3 Kafka wrote his master thesis, 'German and Austrian State Law, Common Law, and Political Economy', with Max Weber's brother, Alfred, at Charles University (Beck Jørgensen, 2012, p. 194; Harrington, 2007; Litowitz, 2002, p. 108; Warner, 2007, p. 1021). Harrington (2007) explains that The Penal Colony echoes and reworks, quite explicitly, in several of its key images and turns of phrase, elements of Alfred Weber's The Civil Servant.

${ }^{4}$ Kafka's admiration for Goethe is well known, but more than The Sorrows of Young Werther it is Leopold von SacherMasoch's Venus in Furs that is an important influence on Kafka's fantasies of the pornographic officialdom (Schaffner, 2012, pp. 197-198).

${ }^{5}$ Kafka makes a comedy out of the desires of officials. In his own love affairs, Kafka did not manifest a 'bureaucratic eros', but a 'poetic eros' manifested, for instance, in his love letters written to his fiancé Felice, who eventually broke off their engagement in a public tribunal (Cannetti, 2012; Corngold, 2007). Spurr (2011, p. 183) mentions that Kafka was still upset when he recalled a conversation he had some 20 years earlier with his father who had advised him to a prostitute in order to learn the facts of sexual life. Kafka styles this autobiographical episode as parental authority pushing the son 'down into the filth' (Spurr, 2011, p. 183). In Kafka's fiction, the degeneration of poetic eros can be found in the metamorphosis of erotic poetry (or Dante's courtly love for Beatrice or Petrarch's courtly love for Laura or Kafka's love for Felice) into Sortini's obscene letters to Amalia. Poetic eros, of course, belongs to the aesthetic sphere, the literary field in particular, given 'the relationship between literary language and love' (Vachhani, 2015, p. 152).

${ }^{6}$ This is not at all to suggest that metamorphosis cannot replace the doctrine of progress or the idea of historical process in the intellectual sphere. Friedrich Nietzsche is the great revolutionary intellectual who makes metamorphosis the core of science. And then science, indeed, becomes a 'gay science' - or, rather, a 'joyous science', to borrow the term from Ralph Waldo Emerson (see Heller, 1988, pp. ix, 181). In the 'joyous science', the distinction between the intellectual and aesthetic sphere is blurred.

7 Pesic (1994, p. 181) stresses that 'Kafka's characters are engaged in ceaselessly searching for the Law.' They are ceaselessly searching because they cannot find the law.

${ }^{8}$ Hannah Arendt stresses that, as a legislator of the literary field, Kafka is the writer who breaks with the classic novel of the $19^{\text {th }}$ century. 'The basis for the classical novel was an acceptance of society as such', Arendt (1994, pp. 78-79) explains. In Kafka's novels, there is no such acceptance: becoming part of society is like signing one's own death warrant.

9 While in this article it is argued that, in Kafka's comedies, the character of protagonists like Joseph K. and the spells of bureaucratic eros are such that heroic resistance to administrative hierarchies is highly limited, Munro and Huber (2012) and McCabe (2014) emphasize the ambiguity of resistance in Kafka's novels. 
10 Kafka refused to move into the intellectual sphere. When in 1915 Martin Buber asked him to contribute to the journal Der Jude, Kafka replied that he was 'far too burdened and insecure to think of speaking up in such company [of Jewish scholars]' (Buber, 1991, p. 182). Later, Kafka did contribute to Der Jude (his 'Jackals and Arabs' and 'A Report to an Academy' were published in 1917) and he encouraged various fellow artists, including the Viennese poet Rudolf Fuchs, the Prague painter Ernst Feigl and Polish Yiddish actor Yitzhak Löwy, to contribute to Buber's journal (Buber, 1991, pp. 217-220).

11 Clearly, Kafka's novels contain illuminating insights and observations. His insights are mainly derived from other novels, such as Von Kleist's Michael Kohlhaas (Kafka claimed to have read Kleist's novella ten times by 1913 (Engelstein, 2006, p. 352), Dickens' David Copperfield, Flaubert's Bouvard and Pecuchet, Dostoevsky's Crime and Punishment and Yiddish theatre plays. Kafka is also, to quite some extent, influenced by scientific works like Alfred Weber's The Civil Servant (Harrington, 2007). And, up to a point, Kafka's insights are rooted in his own experiences as an official. Kafka worked for 14 years as an official at the Workmen's Accident Insurance Institute in Prague, a bureaucratic arm of the Habsburg Empire established to compensate workers for industrial accidents. In this position, Kafka was confronted with the details of industrial technology and the bodily mutilations suffered by workers. He was surprised by how injured workers accepted their injuries as inevitable (Litowitz, 2002, p. 109; Posner, 2010; Robertson, 1985).

12 If any organization in particular, Kafka mostly had the labyrinthian disorientations and Babylonian confusions of the (last days of the) Habsburg bureaucracy in mind (cf. Arendt, 1994, p. 71; Heller, 2009, p. 178), just as Weber mostly had the Prussian bureaucracy in mind.

13 Yet, as Roshwald (2005, p. 374) stresses, the point is that 'today, as we read Kafka, we realize that he had sensed the grim reality which eventually came to pass, and this makes his work prophetic'.

14 A crucial element of this human comedy is, as McCabe (2014, p. 274, 2015, p. 64), rightly notes, is that administrative error and breakdown of machines (and certainly not a well-functioning administrative apparatus) create spaces for escape from repression. Also, hierarchy, Beck Jørgensen (2012, p. 198) points out, is an object of satire, in the sense that 'the Kafkaesque hierarchy appears to be vertically endless'.

15 Elias Cannetti (1984, p. 304), inspired by Kafka, argues that death sentences are the symbolizations of the exercise of authority.

16 In Kafka's novels, both fear and anxiety are key topics. Several of Kafka's protagonists, like Gregor Samsa and Georg Bendemann, are ruled by fear - a fear that is of all times and all epochs because it is the fear that comes with the experience of being dominated or even tyrannized. In contrast with fear, anxiety appears in Kafka's stories as a feature of the 'Era of Organization': it is brought about by the consciousness of one's potentials for meaningful existence that are crushed by organizational forces.

17 As Martin Buber (1991, p. 348), in a letter to Max Brod, a year after the publication of The Trial, exclaims, the Babylonian confusion is such that 'the meaningless has been installed as the executor of meaning'. McCabe (2015) identifies the 'indifference' and the 'turning away from concreteness' as 'the tyranny of distance'. It is a tyranny that is created through bureaucratic ways of organization that makes that people come to act in ways that display little concern for the concrete experiences of others.

18 The 'shades of Kierkegaard's influence' (Warner, 2007, p. 1027) on Kafka's writing are well known. Adorno (1981, p. 261) rightly emphasizes that Kafka 'is Kierkegaard's pupil solely with regard to "objectless inwardness"'.

19 For Kafka as for Weber, America is the world of progress, rationalization, organization. Like other novelists such as Stendhal (in On Love) and Robert Musil (in Grigia), Kafka's America manifests a profound anti-Americanism, in the sense that he presents the brave new world of liberalism in a most unflattering way, namely, as the barbarous world of Taylorism.

${ }^{20}$ And, as Geddes (2015, pp. 403, 404) emphasizes, in the Old Commandant's description of the totem, the pain the machine inflicts on the prisoner is a mere side aspect of the 'hard task' taking place. For the Old Commandant, the pain is merely part of the performance of punishment and justice.

${ }^{21}$ Admittedly, Gregor Samsa does scream, but only because he has a nightmare. After his metamorphosis, he cannot scream because, having turned into a cockroach, he has lost his voice and nobody can hear him anymore.

22 Arendt (1994, p. 70) rightly stresses that in The Trial, 'submission is obtained not by force, but simply through increase in the feeling of guilt of which the unbased accusation was the origin in the accused man'. This feeling, of course, is based in the last instance on the fact that no man is free from guilt.

23 As Spurr (2011, p. 187) puts it, for Kafka 'writing represents the temptation of a way of life completely sealed off from the rest of the world'. 


\section{ORCID}

Marinus Ossewaarde (1) http://orcid.org/0000-0003-3449-1074

\section{REFERENCES}

Adorno, T. W. (1981). Prisms. Cambridge, MA: MIT Press.

Arendt, H. (1994). In J. Kohn (Ed.), Essays in understanding, 1930-1954. New York, NY: Harcourt Brace.

Bakhtin, M. M. (1981). In M. Holquist (Ed.), The dialogic imagination. Austin: University of Texas Press.

Barnard, C. (1954). The functions of the executive. Cambridge, MA: Harvard University Press.

Beck Jørgensen, T. (2012). Weber and Kafka: The rational and the enigmatic bureaucracy. Public Administration, 90, 194-210.

Beer, D. (2016). Fiction and social theory. Theory, Culture \& Society, 33, 409-419.

Bell, E., \& Sinclair, A. (2014). Reclaiming eroticism in the academy. Organization, 21, 268-280.

Benjamin, W. (2007). Illuminations: Essays and reflections. Trans. H. Zohn. New York, NY: Schocken Books.

Bourdieu, P. (1993). The field of cultural production. Cambridge, UK: Polity Press.

Brewis, J., Tyler, M., \& Mills, A. (2014). Sexuality and organizational analysis - 30 years on. Organization, 21, 304-311.

Buber, M. (1951). Two types of faith. London, UK: Routledge \& Kegan Paul.

Buber, M. (1991). In N. N. Glatzer, \& P. Mendes-Flohr (Eds.), The letters of Martin Buber: A life of dialogue. New York, NY: Schocken Books.

Cannetti, E. (1984). Crowds and power. Trans. C. Stewart. New York, NY: Farrar, Strauss and Giroux.

Cannetti, E. (2012). Kafka's other trial. London, UK: Penguin.

Cluley, R. (2014). Sexual fetishism in organizations: The case of journal list fetishism. Organization, 21, 314-328.

de Cock, C., \& Land, C. (2005). Organization/literature: Exploring the seam. Organization Studies, 27, 517-535.

Collinson, M., \& Collinson, D. (1996). 'It's only dick': The sexual harassment of women managers in insurance sales. Work, Employment and Society, 10, 29-56.

Cooke, M. (2014). Truth in narrative fiction: Kafka, Adorno and beyond. Philosophy and Social Criticism, 40, 629-643.

Corbella, W. (2007). Panopticism and the construction of power in Franz Kafka's The Castle. Papers on Language and Literature, 43, 66-88.

Corngold, S. (2007). Kafka \& sex. Daedalus, 136, 79-87.

Danoff, B. (2000). Arendt, Kafka, and the nature of totalitarianism. Perspectives on Political Science, 29, 211-218.

Dekel, E., \& Gurley, D. G. (2015). How the golem came to Prague. The Jewish Quarterly Review, 103, $241-258$.

Deleuze, G., \& Guattari, F. (1986). Kafka: Toward a minor literature. Minneapolis: University of Minnesota Press.

Engelstein, S. (2006). The open wound of beauty: Kafka reading Kleist. The Germanic Review, 81, 349-359.

Fleming, P. (2007). Sexuality, power and resistance in the workplace. Organization Studies, 28, 239-256.

Gabriel, Y. (2012). Organizations in a state of darkness: Towards a theory of organizational miasma. Organization Studies, 33, 1137-1152.

Geddes, J. (2015). Violence and vulnerability: Kafka and Levinas on human suffering. Literature and Theology, 29, 400-414.

Harrington, A. (2007). Alfred Weber's 'The Civil Servant' and Kafka's 'In the Penal Colony': The evidence of an influence. History of the Human Sciences, 20(3), 41-64.

Hearn, J. (2014). Sexualities, organizations and organization sexualities: Future scenarios and the impact of sociotechnologies (a transnational perspective from the global 'north'). Organization, 21, 400-420.

Heller, E. (1988). The importance of Nietzsche: Ten essays. London, UK: The University of Chicago Press.

Heller, E. (2009). The Trial (Franz Kafka). In H. Bloom (Ed.), Alienation (pp. 173-182). New York, NY: Infobase.

Heller, R. (1973). Edvard Munch: The Scream. New York, NY: The Viking Press.

Hodson, R., Martin, A. W., Lopez, S. H., \& Roscigno, V. J. (2012). Rules don't apply: Kafka's insights on bureaucracy. Organization, 20, 256-278.

Hodson, R., Roscigno, V. J., Martin, A., \& Lopez, S. H. (2013). The ascension of Kafkaesque bureaucracy in private sector organizations. Human Relations, 66, 1249-1273.

Huber, C., \& Munro, I. (2014). 'Moral distance' in organizations: An inquiry into ethical violence in the works of Kafka. Journal of Business Ethics, 124, 259-269.

Keenoy, T., \& Seijo, G. (2010). Re-imagining e-mail: Academics in The Castle. Organization, 17, 177-198. 
Kerfoot, D., \& Knights, D. (1998). Managing masculinity in contemporary organizational life: A managerial project. Organization, 5, 7-26.

La Farge, B. (2011). Comic anxiety and Kafka's black comedy. Philosophy and Literature, 35, 282-302.

Land, C., \& Śliwa, M. (2009). The novel and organization. Journal of Organizational Change Management, 22, 349-356.

Litowitz, D. E. (2002). Franz Kafka's outsider jurisprudence. Law and Social Inquiry, 27, 103-137.

McCabe, D. (2014). Light in the darkness? Managers in the back office of a Kafkaesque bank. Organization Studies, 35, 255-278.

McCabe, D. (2015). The tyranny of distance: Kafka and the problem of distance in bureaucratic organizations. Organization, 22, 58-77.

Mishara, A. L. (2010). Kafka, paranoic doubles and the brain: Hypnagogic vs. hyper-reflexive models of disrupted self in neuropsychiatric disorders and anomalous conscious states. Philosophy, Ethics, and Humanities in Medicine, 5, 1-37.

Munro, I., \& Huber, C. (2012). Kafka's mythology: Organization, bureaucracy and the limits of sensemaking. Human Relations, 65, 523-543.

Nasir, M. A. (2012). Logic of the absurd: Reading Kafka in a Kafkaesque world. Administrative Theory and Praxis, 34, 40-59.

Ossewaarde, M. (2013). Theorizing European societies. Basingstoke: Palgrave Macmillan.

Ossewaarde, M. (2015). 'Ismail Kadare's idea of Europe: The dialectic between regime and culture. The European Legacy, 20, 715-730.

Patriotta, G. (2016). Cities of noise: Sensemaking, sensemakers, and organized worlds. Academy of Management Review, 41 , 557-570.

Pesic, P. (1994). Before the law: Einstein and Kafka. Literature and Theology, 8, 174-192.

Posner, R. A. (2010). Kafka: The writer as lawyer. Columbia Law Review, 110, 207-215.

Pullen, A., \& Thanem, T. (2010). Editorial: Sexual spaces. Gender, Work and Organization, 17, 1-6.

Rhodes, C., \& Westwood, R. (2016). The limits of generosity: Lessons on ethics, economy, and reciprocity in Kafka's The Metamorphosis. Journal of Business Ethics, 133, 235-248.

Robertson, R. (1985). Kafka: Judaism, politics, and literature. Oxford, UK: Clarendon Press.

Roshwald, M. (2005). Stefan Zweig and Franz Kafka: A study in contrast. Modern Age, 47, 371-374.

Schaffner, A. K. (2012). Visions of sadistic women: Sade, Sacher-Masoch, Kafka. German Life and Letters, 65, $181-205$.

Shilling, C., \& Mellor, P. A. (2010). Sociology and the problem of eroticism. Sociology, 44, 435-452.

Spurr, D. (2011). Paranoid modernism in Joyce and Kafka. Journal of Modern Literature, 34, 178-192.

Ståhl, O. (2016). Kafka and Deleuze/Guattari: Towards a creative critical writing practice. Theory, Culture \& Society, 33, $221-235$.

Steiner, G. (1980). The death of tragedy. London, UK: Yale University Press.

Tillich, P. (1977). The courage to be. New York, UK: Fontana.

Vachhani, S. J. (2015). Organizing love: Thoughts on the transformative and activist potential of feminine writing. Gender, Work and Organization, 22, 148-162.

Valéry, P. (1989). The outlook for intelligence. Princeton, NJ: Princeton University Press.

Waldo, D. (1968). The novelist on organization and administration: An inquiry into the relationship between two worlds. Berkeley, CA: Institute of Governmental Studies.

Waldo, D. (1984). The administrative state (2nd ed.). London, UK: Holmes \& Meier.

Warner, M. (2007). Kafka, Weber and organization theory. Human Relations, 60, 1019-1038.

Weber, M. (1958). In H. H. Gerth, \& C. Wright Mills (Eds.), From Max Weber: Essays in sociology. New York, NY: Oxford University Press.

Whimster, S. (1995). Max Weber on the erotic and some comparisons with the work of Foucault. International Sociology, 10, 447-462.

Whyte, W. H. (1960). The organization man. Harmondsworth. UK: Penguin.

Younis, M. (2015, August 16). How Isis has established a bureaucracy of rape. The Guardian.

Marinus Ossewaarde is an associate professor in sociology of governance at the University of Twente, The Netherlands. His most recent book is Theorizing European Societies (Basingstoke: Palgrave Macmillan, 2013). He has published a variety of articles on topics like resistance, violence, domination, ideology, cosmopolitanism, 
memory, identity, bureaucracy, publics, commons and dialectic in journals like Organization Studies, Organization, Futures, Current Sociology, Critical Sociology, European Journal of Social Theory, European Societies, Sociology and The European Legacy.

How to cite this article: Ossewaarde M. Kafka on gender, organization and technology: The role of 'bureaucratic eros' in administering change. Gender Work Organ. 2018;1-17. https://doi.org/10.1111/gwao.12278 